\title{
Effect Performance Of Posyandu Toddlers Cadre Against Satisfaction Level Mother Of Toddlers At Posyandu Melati 9 Health Center Liliba Kota Kupang
}

\author{
Joice D Taek, Kristoforus Tnomel, Sefrianus Oeleu \\ Puskesmas Liliba, Kupang, Nusa Tenggara Timur, Indonesia \\ Corresponding author : joicedt17@gmail.com
}

\begin{abstract}
Background: One of the problems that is often faced today is the disability of under-five mothers in obtaining health services for children under five years old because of the lack of performance of Posyandu health workers.

Purpose : The purpose of this research is to know the Effect Performance Of Posyandu Toddler Cadres Against Satisfaction Level Of Toddler Mother At Posyandu Melati 9 Health Center Liliba Kota Kupang

Methods : The design of this study used an observational quantitative approach with cross sectional approach. Respondents were taken with Simple Random Sampling technique. Population studied All Mothers Under Five at Posyandu Melati 9 Puskesmas Liliba Kota Kupang with sample 39 mother. Independent Variables studied is the Performance of Posyandu Toddler and Dependent Variable is the Level of Satisfaction of Under-five Mother. The results were analyzed by using Ordinal Regression statistic test.

Result : The results showed that Kader Performance is known that almost half of the respondents in the Good category is as many as $14(36 \%)$ of respondents. Satisfaction rate of Underfive Mothers is known that most respondents in the category Very Satisfied is as much as $20(51 \%)$ respondents. The result of data analysis shows that the significance level of $0,000<\alpha=0.05$ so that $\mathrm{H} 0$ is rejected and H1 is accepted thus There is Effect Performance Of Posyandu Toddler Cadres Against Satisfaction Level Of Toddler Mother At Posyandu Melati 9 Health Center Liliba Kota Kupang.

Conclusion : Based on the result of the research, it is known that the satisfaction of mother of balita to posyandu service where cadre always do monitoring and evaluation to posyandu. Besides, it is also supported by cadre training and comparative study of posyandu cadres to other posyandu as a learning media so that they can follow the improvement effort that has been done.
\end{abstract}

Keywords : Performance Of Posyandu Toddler Cadres, Satisfaction, Toddler Mother

Received: February 03, 2018; Revised February 24, 2018; Accepted March 10, 2018

How to Cite: Taek, D.J., Tnomel, K., \& Oeleu, S., (2018). Effect Performance Of Posyandu Toddlers Cadre Against Satisfaction Level Mother Of Toddlers At Posyandu Melati 9 Health Center Liliba Kota Kupang. Journal Of Nursing Practice. 1(2). 33-40 


\section{BACKGROUND}

Satisfaction is a function of the difference between perceived performance and expectations. The new patient will be satisfied if the healthcare performance is equal to or exceeding expectations and vice versa, patient dissatisfaction or feelings of disappointment will arise if the health care performance is not as expected. Customer satisfaction is determined by customer perceptions of product or service performance in meeting customer expectations. Customers are satisfied if their expectations are met or will be very satisfied if customer expectations are exceeded (Nugroho, 2010).

The Central Sulawesi Health Office found that most cadres $(83.2 \%)$ said that facilities such as KMS / KIA, record books, weighing instruments, immunization materials and polio drops, medicines (vitamins A and Fe) were available at posyandu. While the number of active cadres in Posyandu between $2-3$ people $(77.3 \%$ ), on the contrary the user reached $(97.9 \%)$, but the cadre awareness level provided service at posyandu every month reached $(65.9 \%)$. This means there is a positive and significant relationship between the motivation of cadres and users on the opening day of posyandu (Central Sulawesi Health Office, 2016).

Based on the result of Sugi Purwanti (2015) study, it is known that according to the community, the performance of Posyandu officers is $29(43,94 \%)$ and at least 18 officers $(27,27 \%)$. While the picture of satisfaction level of mother of balita at posyandu majority of satisfaction level of mother in category satisfied enough 30 people $(45,46 \%)$ and 18 people $(27,27 \%)$ into less satisfied category. There are some things that according to the mother of toddler still less according to their desire about good posyandu service like skill officer $40,91 \%$ dissatisfied, communication $24,24 \%$ not satisfied, handling of complaint $34,85 \%$ dissatisfied, giving comfort $36,36 \%$ not satisfied.

According to the Health Profile of Nusa Tenggara Timur in 2017, in 2016 the number of posyandu has decreased by 530 posyandu compared to 2014 from 46,275 to 45,745. Similarly, the number of active cadres which in 2016 decreased 46,652 cadres compared to 2014 from 194,552 cadres to 147,900 cadres. Based on Kupang Puskesmas Report 2014, the coverage of D / S is $69.03 \%$ and in 2015 is $67.08 \%$ and all have not reached $80 \%$ target. On the other hand, knowledge about the existence of posyandu is $65.2 \%$, the highest in West Java (78.2\%) and the lowest in Bengkulu (26.0\%) (Trihono, 2013).

Data on the number of active cadres in Posyandu Melati 9 Puskesmas Liliba Kupang City is as many as 10 cadres while the coverage of the number of infant mothers is as many as 48 mothers under five. Preliminary study conducted by researchers at Posyandu Melati 9 Puskesmas Liliba Kota Kupang on December 5, 2016 to 10 mother toddlers where it is known that 5 mother toddler said posyandu cadres are often not present when posyandu schedule with reason out of town or even do not remember posyandu schedule. Besides, the delay of the cadres visited posyandu to be one bad example where this is supported by observation result conducted by the researcher. 3 mother said that communication between cadres with mother of toddler often misunderstanding because of unavailability of vaccine for children even injectable contraceptive drugs that are not available every month. So when the posyandu of injecting drug contraception should be paid by the mother of a toddler. While 2 mothers of children under five said that the skills and knowledge of the cadres have been good because it is supported by long work as a cadre officer in the community and also various training and guidance provided by health workers (Study Results Introduction In Posyandu Melati 9 Puskesmas Liliba Kota Kupang, 2016).

Performance of public services one of the demands to be fulfilled is the satisfaction of customers served. Including posyandu as Community Based Health Effort (UKBM) which 
incidentally from, by and for society, also should be able to give satisfaction of its target. Satisfaction according to Oliver as quoted Sari (2008) is the level of one's feelings (customers) after comparing the performance or perceived results (service received and perceived) with the expected. Technically posyandu cadres must show their best performance so that the people served are satisfied.

The success of posyandu is highly determined by the performance of the cadres, because the cadres are the posyandu activator and the life of the posyandu's death depends on whether or not the cadre is active. Not infrequently due to the lack of attention from the Village Head, the Head of TP PKK, and the Puskesmas officers towards the cadres and posyandu make Posyandu become increasingly withered (DepKes, 2014).

Therefore, considering the above problems, to improve the satisfaction of the mother of the children to posyandu services, it is necessary to monitor and evaluate the posyandu. Assessment of posyandu strata conducted so far needs to be carried out continuously. Training of posyandu cadres in a certain period of time should also be done. Comparative studies of posyandu cadres to other posyandu should also be done as adult learning media so that they can follow the improvement efforts that have been done. It is also necessary to conduct a study on community satisfaction on posyandu services.

Besides, awards are also given to increase the motivation of the cadres should always be there. A cadre who has high motivation and good ability in carrying out his duties will produce good performance. Provision of incentives and rewards are considered to increase the motivation of cadre performance because the motivation of cadres in the implementation of posyandu is a dominant factor that is very influential on the utilization rate of balita balita.

Based on the above phenomenon, the researcher is interested to carry out the research entitled "The Influence of Performance of Posyandu Cadre of Toddlers Against Satisfaction Level of Toddler Mother at Posyandu Melati 9 Puskesmas Liliba Kota Kupang".

\section{OBJECTIVE}

To know the knowledge and role of nurses in the implementation of emergency patient handling with cardiovascular system disorder.

\section{METHODS}

The design of this study used an observational quantitative approach with cross sectional approach. Respondents were taken with Simple Random Sampling technique. Population studied All Mothers Under Five at Posyandu Melati 9 Puskesmas Liliba Kota Kupang with sample 39 mother. Independent Variables studied is the Performance of Posyandu Toddler and Dependent Variable is the Level of Satisfaction of Under-five Mother. The results were analyzed by using Ordinal Regression statistic test. Data analysis technique used to test the Influence of Performance of Posyandu Toddlers Cadre On Satisfaction Level of Toddler Mother at Posyandu Melati 9 Kota Kupang by using Ordinal Regression statistic test to know the influence of independent variable to dependent variable with trust level $\alpha$ $=0,05$. 


\section{RESULTS}

Table 1. Performance of Posyandu Toddler Cadre At Posyandu Melati 9 Puskesmas Liliba Kota Kupang

\begin{tabular}{cccc}
\hline No & Performance & Frekuensi & $(\%)$ \\
\hline 1. & Lack & 14 & $36 \%$ \\
2. & Enough & 11 & $28 \%$ \\
3. & Good & 14 & $36 \%$ \\
Total & & 39 & $100 \%$ \\
\hline
\end{tabular}

Based on table 1 Performance of Posyandu Posyandu Balita In Posyandu Melati 9 Puskesmas Liliba Kota Kupang it is known that almost half of the respondents in the Good category are as many as $14(36 \%)$ of respondents.

Table 2. Level of Satisfaction of Under Fives at Posyandu Melati 9 Puskesmas Liliba Kota

\begin{tabular}{cccc}
\multicolumn{2}{c}{ Kupang } & & \\
\hline No & Satisfaction & Frekuensi & $(\%)$ \\
\hline 1 & Very Dissatisfied & 5 & $13 \%$ \\
2 & Dissatisfied & 9 & $23 \%$ \\
3 & Satisfied & 5 & $13 \%$ \\
4 & Very satisfied & 20 & $51 \%$ \\
Total & & 39 & $100 \%$ \\
\hline
\end{tabular}

Based on table 2 Level of Satisfaction of Mother Toddler at Posyandu Melati 9 Puskesmas Liliba Kupang City known that most of respondent in category Very Satisfied to performance of posyandu cadre is as much as $20(51 \%)$ respondents.

The result of data analysis showed that Kader Performance with significance level 0,000 $<\alpha=0.05$ so that $\mathrm{H} 0$ rejected and H1 accepted thus There is Influence Performance Cadre Posyandu Toddler In Posyandu Melati 9 Puskesmas Liliba Kota Kupang. While the level of Satisfaction of Mother of Toddler with significance level $0,000<\alpha=0,05$ so that $\mathrm{H} 0$ rejected and $\mathrm{H} 1$ accepted thus There is Influence of Satisfaction Level of Mother Toddler at Posyandu Melati 9 Puskesmas Liliba Kota Kupang

\section{DISCUSSION}

\section{Performance of Posyandu Toddler Cadre at Posyandu Melati 9 Puskesmas Liliba Kota Kupang}

Based on the results of the research, it is known that the Performance of Posyandu Toddler Cadid Di Posyandu Melati 9 Puskesmas Liliba Kota Kupang is known that almost half of the respondents in the Good category are $14(36 \%)$ respondents. This is supported by the presence of cadres during the posyandu schedule, information and knowledge of cadres to the service, the availability of complete facilities and infrastructure at posyandu, cadre skills in providing services, interaction and good communication between cadres and mothers. Performance of cadres in the category of Enough is as much as $11(28 \%)$ of respondents where marked with skilled cadres in providing services to the mother of the toddler as well as weighing balita appropriate to the age of toddlers and vaccines given to toddlers while the category Less is as many as $14(36 \%)$ respondents where it was marked by several cadres who arrived late when the posyandu schedule. this is supported by the cadre's statement that the busyness of the household is like taking care of the children to go to school which causes the delay of visiting cousins of the pesosandu. 
Performance of public services one of the demands to be fulfilled is the satisfaction of customers served. Including posyandu as Community Based Health Effort (UKBM) which is in fact from, by and for society, it is also appropriate to give satisfaction of its target (Sari, 2016).

The success of posyandu is highly determined by the performance of the cadres, because the cadres are the posyandu activator and the life of the posyandu's death depends on whether or not the cadre is active. Not infrequently due to the lack of attention from the Village Head, the Head of TP PKK, and the Puskesmas officers towards the cadres and posyandu make Posyandu become increasingly withered (DepKes, 2014).

According to the researcher's opinion that the cadre's performance in providing optimal service is supported by the presence of cadres during the posyandu schedule, information and knowledge of cadres towards the service, the availability of complete facilities and infrastructure in posyandu, cadre skills in providing services, interaction and good communication between the cadres with a toddler mother.

Based on the results of cross-tabulation between Age and Performance of Posyandu Toddlers Cadre at Posyandu Melati 9 Puskesmas Liliba Kota Kupang it is known that almost half of the respondents with age $25-30$ years in Good category is as much as 9 $(43 \%)$ respondents. This is supported by the increasingly mature cadres so that in providing services always supported by good performance with information and knowledge so that the service provided was in accordance with the wishes of the mother of the toddler.

A person's age is closely related to the education and knowledge of cadres about the benefits or importance of posyandu toddlers where the more mature one's age then the level of maturity and strength of a person will be better in thinking and determining health attitudes and behaviors, especially in providing services for maternal satisfaction (DepKes, 2014) .

Therefore, according to the opinion of the researcher that with the age of the cadres are more mature so that in providing services always supported by good performance with information and knowledge so that the service provided was in accordance with the wishes of the mother of the toddler.

Based on the result of cross tabulation between Education and Performance of Posyandu Balita Cadre at Posyandu Melati 9 Puskesmas Liliba Kota Kupang it is known that almost half of respondents with high school education level in Good category is 12 (41\%) respondents. This is supported by the optimal cadre education about posyandu balita and also material obtained from health officer about the importance of 5 tables that applied by the service center so that the mother of toddler is able to apply it well at posyandu schedule.

Education is an experience with that experience, a person or group of people can understand something they did not understand before. The experience happens because there is interaction between a person or a group with the environment. The interaction leads to a process of change (learning) in humans and then the process of change that produces development (development) for the life of a person or group in the environment (Notoatmodjo, 2010).

In the opinion of researchers that education posyandu cadres are able to add insight into optimizing thinking activities conducted as well as posyandu toddler activities. With information and knowledge owned by the cadres so that in the implementation of the activity there is no error in the service. 
Based on the result of cross tabulation between the Work and Performance of Posyandu Toddler Cadre at Posyandu Melati 9 Puskesmas Liliba Kupang City it is known that almost half of the respondents work as Traders in the Enough category are 7 (35\%) respondents. This is supported by the attitude and behavior of mothers who always take the time to deliver their children when the posyandu schedule so that children always get health services posyandu regularly.

Work is a set of positions that have the same liability or duties. In a job analysis activity, one job can be occupied by one person, or multiple people scattered in various places. In a broad sense Work is the main activity undertaken by humans. In a narrow sense, the term work is used for a task or work that earns money for a person. In everyday conversations the term is often considered synonymous with the profession (Adi, 2014).

In the opinion of the researcher that with attitude and behavior of mother always take time to deliver their child when posyandu schedule so that child always get health service posyandu with regular

\section{Level of Satisfaction of Under Fives at Posyandu Melati 9 Puskesmas Liliba Kota Kupang}

Based on the results of the research, it is known that Maternal Satisfaction Level In Posyandu Melati 9 Puskesmas Liliba Kupang City is known that most respondents in the category of Very Satisfied is as much as 20 (51\%) of respondents. This is supported by the satisfaction of the mother of toddler to cadre service such as interaction / communication between cadres with mother of balita, presence of cadre before activity started, availability of facilities and infrastructure of posyandu and others.

Satisfaction is a function of the difference between perceived performance and expectations. The new patient will be satisfied if the healthcare performance is equal to or exceeding expectations and vice versa, patient dissatisfaction or feelings of disappointment will arise if the health service performance is not as expected (Tjiptono, 2010).

Customer satisfaction is determined by customer perceptions of product or service performance in meeting customer expectations. Customers are satisfied if their expectations are met or will be very satisfied if customer expectations are exceeded (Nugroho, 2010).

According to the researcher's opinion that the satisfaction of the mother of toddler to the service of cadre which supported by the accuracy of cadre in giving service to children like giving the vaccine according to the age of the toddler beside that cadres always pay attention to the giving of the vaccine to the toddler if the toddler is sick. This becomes one of the actions that cause the consumer / mother toddler to feel happy about the skill of the cadre during the activity.

The Influence of Performance of Posyandu Toddler Cadres Against Satisfaction Rate of Under Fives at Posyandu Melati 9 Puskesmas Liliba Kota Kupang

The result of data analysis shows that the significance level of $0,000<\alpha=0.05$ so that $\mathrm{H} 0$ is rejected and H1 is accepted thus There is Influence Performance of Posyandu Toddler Cadre Against Satisfaction Level of Toddler at Posyandu Melati 9 Puskesmas Liliba Kota Kupang.

One of the problems that is often faced today is the lack of satisfaction of under-five mother in getting health service of children under five years old because of the lack of performance of Posyandu health officer in this case the absence of cadre during posyandu schedule, lack of knowledge of cadre to service, lack of complete facilities and 
infrastructure at posyandu, cadre delays visited posyandu, staff skills, communication and so on (Avicena, 2015).

Satisfaction is a function of the difference between perceived performance and expectations. The new patient will be satisfied if the healthcare performance is equal to or exceeding expectations and vice versa, patient dissatisfaction or feelings of disappointment will arise if the health care performance is not as expected. Customer satisfaction is determined by customer perceptions of product or service performance in meeting customer expectations. Customers are satisfied if their expectations are met or will be very satisfied if customer expectations are exceeded (Nugroho, 2010).

Performance of public services one of the demands to be fulfilled is the satisfaction of customers served. Including posyandu as Community Based Health Effort (UKBM) which incidentally from, by and for society, also should be able to give satisfaction of its target. Satisfaction according to Oliver as quoted Sari (2008) is the level of one's feelings (customers) after comparing the performance or perceived results (service received and perceived) with the expected. Technically posyandu cadres must show their best performance so that the people served are satisfied.

The success of posyandu is highly determined by the performance of the cadres, because the cadres are the posyandu activator and the life of the posyandu's death depends on whether or not the cadre is active. Not infrequently due to the lack of attention from the Village Head, the Head of TP PKK, and the Puskesmas officers towards the cadres and posyandu make Posyandu become increasingly withered (DepKes, 2014).

Therefore, considering the above problems, to improve the satisfaction of the mother of the children to posyandu services, it is necessary to monitor and evaluate the posyandu. Assessment of posyandu strata conducted so far needs to be carried out continuously. Training of posyandu cadres in a certain period of time should also be done. Comparative studies of posyandu cadres to other posyandu should also be done as adult learning media so that they can follow the improvement efforts that have been done. It is also necessary to conduct a study on community satisfaction on posyandu services

\section{CONCLUSION}

Performance of Posyandu Kader Balita In Posyandu Melati 9 Puskesmas Liliba Kota Kupang it is known that almost half of the respondents in the Good category are $14(36 \%)$ of respondents.

Maternal Satisfaction Level at Posyandu Melati 9 Puskesmas Liliba Kota Kupang is known that most respondents in the category of Very Satisfied is as much as 20 (51\%) of respondents.

The results of data analysis showed that the level of significance $0.000<\alpha=0.05$ so that $\mathrm{H} 0$ rejected and $\mathrm{H} 1$ accepted thus There is Influence Performance Cadres Posyandu Toddlers Against Satisfaction Levels Under Fives at Posyandu Melati 9 Puskesmas Liliba Kota Kupang.

\section{REFERENCES}

Adi, Isbandi Rukminto. 2014. Psikologi, Pekerjaan Sosial dan Ilmu Kesejahteraan Sosial: Dasar-dasar Pemikiran.Jakarta: PT Raja GrafindoPersada.

Avicena, 2015. Kepuasan Ibu Balita Berkunjung Ke Posyandu. Surabaya : Dinkes Jatim. 
DepKes RI. 2014. Profil Kesehatan Indonesia 2014 : Menuju Indonesia Sehat 2015. Jakarta : Departemen Kesehatan RI.

Hurlock, Elizabeth. 2010. Psikologi Perkembangan Suatu Pendekatan Sepanjang Rentang Kehidupan. Jakarta:Penerbit Erlangga.

Ilyas, Y. 2009. Kinerja : Teori Penilaian dan Penelitian. Jakarta : FKM UI.

Kamus Besar Bahasa Indonesia (KBBI) (2010). Konsep Pendidikan. Jakarta : Rineka Cipta.

Notoatmodjo, Soekidjo. 2010. Pendidikan dan Perilaku Kesehatan. Jakarta : Rineka Cipta.

Sari, 2016. Kualitas dalam Goetsh dan Davis. Kualitas Pelayanan. Gramedia Indonesia : Jakarta.

Sari. W, Irine Diana. 2010. Manajemen Pemasaran Usaha Kesehatan. Cetakan Keempat. Yogyakata: Nuha Medika.

Setiadi, J Nugroho. Perilaku Konsumen, Jakarta : Kencana Prenada Media Group, 2010.

Tjiptono, Fandy. 2010. Strategi Pemasaran, Edisi 2, Andi Offset, Yogyakarta 